\title{
Stalemates to Democracy in Nigeria: The Paradoxes of Human Rights and Social Justice
}

\section{Oguejiofo C. P. Ezeanya}

University of Nigeria, Nsukka

\begin{abstract}
Ever since independence in 1960 Nigeria has struggled with vestiges of colonialism rooted in the divide-and-rule legacy of the British. The postcolonial society has witnessed paradoxical authority patterns entrenched in 'democratic and military dictatorships' which undermine civil rights and social justice, and clamp down on human rights struggles. Peace and security have been in abeyance due to bad leadership that fails to utilize the advantage of the socio-cultural and ethnic diversities of Nigerian peoples. Certain provisions of the Nigerian constitution seem to support these anomalies, and Nigerian leaders have not shown the willpower to change the status quo. Authors and activists have challenged this ugly trend. This paper seeks to address the inhibitions to viable democracy in Nigeria. It points out some constitutional shortcomings that encourage bad leadership and disrespect for human rights, and recommends a recreation of standard that would ensure a meaningful democracy in the country.
\end{abstract}

\section{INTRODUCTION}

The foundation of the Nigerian state was laid on a faulty ground as the British colonialists merely joined some of their protectorates and named them Nigeria in 1914, without seeking for, and getting the people's consent. A 'dictatorial martial laws', may better describe what is called the Constitution of the Federal Republic of Nigeria 1999, as it was handed down to Nigerians by Decree No. 24 of 1999 in the military regime of General Abdulsallam Abubakar, and although it is excessively criticized as undemocratic and a lot of its pro-

Social Evolution \& History, Vol. 17 No. 1, March 2018 140-159

(C) 2018 'Uchitel' Publishing House

DOI: $10.30884 / \mathrm{seh} / 2018.01 .08$ 
visions are unacceptable to Nigerians, it is still the supreme law of the land to date. This does not allow growth and egalitarianism among citizens of the country. The serious lapses contained in the laws give room for various degrees of corruption in high and low places and heat up the polity with public unrest.

Widespread resentment, lawlessness, anarchy, terrorism and a fullblown war have characterized life in Nigeria since its emergence as a country. For the peoples put together as one the amalgamation itself became a forced marriage of unwilling partners; such that right from the onset both the colonialists and the prominent indigenous leaders of the people were skeptical of the possible survival of the country as a nation (Crowder 1966: 23). Some prominent Nigerian leaders such as Abubakar Tafawa Belewa, Ahmadu Bello, Obafemi Awolowo, and Yakubu Gowon, made statements that clearly show their loss of confidence in the unity and nationhood of Nigeria (Uwalaka 2003: 50).

Several coup d'états and military interventions in Nigerian politics have taken advantage of the bad leadership in the country to thrive; yet the military continued the ugly trend of bad leadership in worse proportions. At a stage the country had to engage in a civil war which worsened the post-war leaders' obstinacy in injustice and nonegalitarianism in dealing with citizens of the one country. The Niger Delta militancy campaign is another unrest that loudly clamored for redress of governmental proneness to injustice along ethnic lines. The campaign nearly degenerated into a second civil war but was only placated with the amnesty programme that merely distracted the militants without actually addressing the wholesome challenges posed by their courageous agitations.

The menace of the Boko Haram terrorists has dealt Nigeria a very deadly blow, and their mayhem is not yet over. The proponents demand for strict Islamic religious law for the country even if the country is taken as a secular state, though dictatorially registered as a member of the Organization of Islamic Cooperation in 1986 (Permanent Observer Mission to the United Nations... 2011: Online 18/3/17). Nobody knows where the looming rain of the highly organized and peopled campaign of the Indigenous People of Biafra (IPOB) would place the country Nigeria if all in their arsenal are allowed to be let loose as the members bitterly complain of a worse situation people from their former Eastern Nigeria are consciously placed by the Nigerian government after they lost the war they fought half a century ago under the umbrella of the Republic of Biafra. 
Several write-ups have appeared on the problems with Nigeria all of which seemed to have fallen on deaf ears. One of the greatest writers of the contemporary times, Chinua Achebe, who was also a Nigerian, explored the shortfalls in Nigerian democracy in the narrative artfully presented in his Anthills of the Savannah, and heaped the blame on the country's leadership; but the country did not get better with his prophetic words that keep fulfilling repeatedly to the woes of the country. Each government that emerges in Nigeria generally talks of its willingness to promote democracy and the respect of human rights and freedom - even military dictatorships claim so while promising quick transition to civil rule; yet respect for human rights and egalitarianism continuously elude Nigerians. A review of the constitutional democracy in Nigeria will throw more light on this problem.

\section{CONSTITUTIONAL DEMOCRACY IN NIGERIA}

Going by a comparative analysis of certain provisions of the 1999 Constitution of the Federal Republic of Nigeria with the standard of democracy in other modern Constitutions it appears that Nigeria attempts to set up a democratic government (Aguda 1983: 33). For the fact that power intoxicates and absolute power corrupts absolutely, the powers of government are divided into three arms - Legislative arm (section 4), Executive arm (section 5), and Judicial arm (section 6). This is meant to ensure separation of powers with the necessary checks and balances that help in good governance by preventing arbitrariness and selfish exercise of governmental power.

It is informed by the fact that power belongs to the people, and as such when a few individuals in a particular arm of government decide to lord it over the people, the other two arms would checkmate them. Every standard Constitutional democracy enshrines separation of powers in the country'spolicy. Nigerian presidential democracy accommodates the doctrine of separation of powers in its Constitution. By delineating the domains of the Legislative, Executive and Judicial arms of government with different functions and each complementing the others, abuse of power is ordinarily sought to be guarded against. As famous Nigerian jurist Oputa (1998: 173) puts it:

The concept of separation of powers arose from the need 'to ensure the restraint of governmental power by dividing that power, without carrying that division to an extreme, incompatible with effective government.' A constitutional democracy thus pre-supposes a balanced system of divided or shared powers. It is only within such a system that indi- 
vidual citizens can ever hope to enjoy any measure of independence and freedom from arbitrariness and governmental lawlessness and thus enjoy the civil rights and liberties conferred on them by our Constitution.

The judiciary in a special way plays a pivotal role as the last hope of the common man in the face of legislative or executive injustices. The people in a democratic society have hopes and expectations from the government for which they agreed to be bound together by the Constitution. It is to the extent at which these hopes and expectations are satisfied or abused that a stable and civilized democracy is measured. Nigerians want good governance and a stable democracy. Chapter two of the 1999 Constitution, which covers sections 13-24, has mouth-watering provisions as it projects government policies that would meet the aspirations of egalitarian democracy in Nigeria. Yet all the provisions of the chapter two were made non-justiciable, which means that nobody may challenge in court the non-fulfillment of any part of that chapter by government. Section $14(1-2)(a-c)$, which is part of the chapter two, provides as follows:

The Federal Republic of Nigeria shall be a State based on the principles of democracy and social justice. It is hereby, accordingly, declared that sovereignty belongs to the people of Nigeria from whom government through this Constitution derives all its powers and authority; the security and welfare of the people shall be the primary purpose of government; and the participation by the people in their government shall be ensured in accordance with the provisions of this Constitution.

By this constitutional provision the Nigerian State is designed to be a democratic one, and apply justice and fair play in every activity within the polity. The people of Nigeria are also made the sovereigns who delegate power to some people to exercise based on the purported mutual agreements enshrined in the Constitution. As the sovereign, the people should have the greater say and stake in determining what happens in the polity than those in the government. In this exercise of sovereignty it is presumed that the people of Nigeria insist that those in government should ensure security and welfare of Nigerians under the law as the primary purpose for which they are put in government. Unfortunately the same constitution, in section 308 granted some key government officials immunity from litigation while in office, such that none of their actions may be challenged in court. It provides thus: 
308-(1) Notwithstanding anything to the contrary in this Constitution, but subject to subsection (2) of this section

(a) no civil or criminal proceedings shall be instituted or continued against a person to whom this section applies during his period of office;

(b) a person to whom this section applies shall not be arrested or imprisoned during that period either in pursuance of the process of any court or otherwise; and

(c) no process of any court requiring or compelling the appearance of a person to whom this section applies, shall be applied for or issued ...

(2) The provisions of subsection (1) of this section shall not apply to civil proceedings against a person to whom this section applies in his official capacity or to civil or criminal proceedings in which such a person is only a nominal party

(3) This section applies to a person holding the office of President or Vice President, Governor of Deputy Governor; and the reference in this section to 'period of office' is a reference to the period during which the person holding such office is required to perform the functions of the office.

When section 6 on the judiciary had defined the extent of the exercise of judicial powers it also went further to define some areas where the judicial power may not extend. Section 6 (6) (c-d) therefore provides that:

The judicial powers vested in accordance with the foregoing provisions of this section shall not, except as otherwise provided by this Constitution, extend to any issue or question as to whether any act or omission by any authority or person or as to whether any law or any judicial decision is in conformity with the Fundamental Objectives and Directive Principles of state Policy set out in Chapter II of this Constitution; and shall not, as from the date when this section comes into force, extend to any action or proceedings relating to any existing law made on or after $15^{\text {th }}$ January, 1966 for determining any issue or question as to the competence of any authority or person to make any such law.

By these reservations the judiciary has been incapacitated from handling cases bordering on chapter two of the Constitution, which 
would have been the crux of ensuring that the dividends of democracy are adequately distributed to the citizenry. It also stopped the judiciary from adjudicating over the credibility of the acts of the military dictatorship that disjointed the flow of democratic government on $15^{\text {th }} \mathrm{Jan}$ uary 1966 and from time to time in Nigeria. It has clawed-back the wonderful democratic rights of redress already granted in respect to the functions of the judiciary. That is why even the Constitution is often hotly criticized as inadequate, having originated from a military regime whereby the military dictators patterned the Constitution to suit their selfish interests and handed it down to Nigerians without public dialogue with stakeholders; and the military junta intend to contest election (or continue in leadership) transformed as civilians.

National prosperity and avoidance of the concentration of wealth among few people are some of the many other constitutional aspirations of the people of Nigeria to whom sovereignty belongs. Neglect of these aspirations always has a lot of negative consequences. It would not be an overstatement to say that in Nigeria those provisions of Chapter II of the Constitution which should direct the people in government on the expectations of the people they are supposed to serve in good governance have all been abused beyond imaginable proportions such that those in government have taken more than the owners of sovereignty could reasonably be expected to condone.

Even the electoral process for choosing those to be in government is already a tale of woes in the country. The people's choice is never respected; people maneuver their ways into positions of power with impunity even where the whole world cries foul. Lynching of political opponents and critics seems more normal than an exception. The Nigerian State has been sent centuries back the ladder of viable democracy by these anomalies. Obegolu (1999: 52-53) correctly pictures this situation in the country as he writes:

It is obvious that the state of litigations after an election by way of election petitions is as a result of lack of faith in the conduct of elections. That elections are fought here in Nigeria and some other few countries, as a do or die affair, is not in doubt. That rigging is part of the game is doubtless. In fact the slogan is that the winners in most cases are those who are able to out rig the other by way of financial power used in buying the electoral officials and other connections.

It is for the above reasons and more that Nigerian democracy has always rested on a highly vulnerable and shaky pivot, and the judici- 
ary, which is the last hope of the common man in a democracy, is tasked with enormous obligation to strike a redress. Abraham Lincoln is truly right in maintaining that 'no man is good enough to govern another man without his consent' (Obegolu 1999: 155).

\section{STRUGGLE FOR RIGHTS AND JUSTICE IN NIGERIA}

Democracy is built on the respect for human rights and social justice. Human rights are better described than defined. The concept of human rights is the modern articulation of what traditionally is known as natural rights (Ezejiofor 1999: 1). It is a recapitulation of those rights that accrue to humans everywhere and at all times for the fact that they are human beings as differentiated from animals. As moral and rational beings people already know without being told that certain things are good and are to be done, while others are bad and are to be avoided. Hence human rights may be defined as moral and natural rights which human beings ought to enjoy as rational and moral beings.

Social justice as a concept has an etymology derived from the Hebrew word (sadeqeh), which in Greek is represented as dikaiosune (dikaiosune), meaning style of action in relation to partnership with others. It entails the justice that regulates the norms of action guiding inter-human relationships. Also (sadeh) is used to signify: 'To let the innocent have his due', to 'justify him', while (טפשמ(mispat) is used to indicate the yardstick for social justice for the lovers of peace, as exemplified in Ezekiel 18: 5-9. Hence social justice entails both the respecting of other people's due and the conducting of one's self in a gentle manner (Berger 1989: 231-232).

Democracy is meant to protect human rights and social justice, and where such protection is lacking the struggle for their actualization continues, as in the case of Nigeria. Without overlabouring the obvious fact of slave trade and colonization as climaxing the disrespect of human dignity and rights, the struggle for human rights in Nigeria is as old as the country itself. Independence from colonialism was fought and won in 1960 from the British colonialists, but as they were leaving they planted a perennial tree of corruption that seems to perpetuate denial of human rights in Nigeria. Chinua Achebe (2012: 50-51) aptly presents the fact of how the British rigged the very first election in Nigeria to favour their northern favorites:

It is now widely known that Sir James Robertson played an important role in overseeing the elections (or lack thereof) at independence, throwing his weight behind Abubakar Tafawa Belewa, who had been tapped to become Nigeria's 
first prime minister... Later it was discovered that a courageous English junior civil servant named Harold Smith had been selected by no other than Sir James Robertson to oversee the rigging of Nigeria's first election 'so that its compliant friends in (Northern Nigeria) would win power, dominate the country, and serve British interests after independence'. ... In a sense, Nigerian independence came with a British governor general in command, and, one might say, popular faith in genuine democracy was compromised from its birth.

Corruption breeds bad government; consequently the first republic of Nigeria began immediately to experience political tensions based on bad government until the military struck in 1966 coup d'état that followed. The same year witnessed the pogrom against the Igbo in different parts of the country which made the Igbo and other indigenous peoples of the eastern region of the country to secede and identify themselves as the Republic of Biafra in 1967. The aggravation of the struggle for self-determination and respect of human rights against unjust oppressions in Nigeria led to the thirty months civil war in the country, which claimed more than one million lives in what is variously described as a genocide against the Igbo of Nigeria.

Kurt Vonnegut (1974) who was an eye-witness of the war, wrote an article he entitled Biafra: A People Betrayed in which he narrated the climax of disrespect of human rights and dignity perpetrated against Biafra, and the unwholesome response of some world powers to the cause of justice and respect of human life and dignity, simply for the actualization of selfish interests. Nearly half a century since the end of the civil war in 1970, the unbearable and dehumanizing actions against the Igbo of Nigeria still continued, and several other parts of Nigeria still cry foul of the vindictive and biased approach of government to their human rights and dignity.

On Thursday, 17 March 2016 Godswill Akpabio (2016: Online 18/3/17) who is the minority leader in Nigerian Senate, and the immediate past governor of Akwa-Ibom State, gave a lecture entitled 'The Nigerian Question: Ethics in an Age of Uncertainty', at the $17^{\text {th }}$ Convocation ceremony of Chukwuemeka Odumegwu Ojukwu University (COOU) Igboariam, whereby he extolled the virtues of the Biafran warlord (Ojukwu) in fighting the cause of justice for the Igbo of Nigeria, and decried the culpable negligence of past leaders of Nigeria that lingered into the current devastating acts of violence virtually everywhere in Nigeria today. In his words: 
If our past leaders had done the needful without bearing in mind sectional interests, the Nigerian civil war would have been averted...the bloodshed we are seeing in this country wouldn't have been necessary if our children were taught the history of how we were able to collectively, in brotherhood obtain independence without firing a gun... we cannot sustain that independence with the explosions in the Niger Delta, Boko Haram in the North, Odua Peoples Congress (OPC) in the West and now Indigenous People of Biafra (IPOB) in the East.

The true picture painted in the quotation above shows that virtually all regions that make up the ethnic groupings in Nigeria are struggling to be free from one form of dehumanizing actions or inactions of the government of Nigeria or the other. Everyone is suspecting and blaming everyone and it seems as if the circle of doom is endless. The country that now bleeds with activities of terrorists here and there had been warned in various ways and times by wise men of the impending doom but the leaders could not summon the courage to change things for the better. It is as if they prefer the situation where a few privileged people enjoy the enormous goodies of the country while the great majority of the citizens cry and die of avoidable injustice. The narrative of Chinua Achebe on the Anthills of the Savannah prophesied to this effect several decades ago. A gist of that narrative suffices in corroborating the argument.

\section{ANTHILLS OF THE SAVANNAH NARRATIVE}

The book 'Anthills of the Savannah' written by Chinua Achebe was first published in 1987 during the military regime that caused several atrocities against human rights and dignity in Nigeria that shocked the whole world. The key actors in the narrative are three old school friends Sam, Chris, and Ikem, who were the prominent members of the military administration. Sam was the military dictator and Head of State, Chris was the Commissioner of Information, while Ikem was the Editor of the National Gazette Newspaper. It was a reign of terror whereby Sam, ordinarily called His Excellency, was a law unto himself, to the extent that all the members of his cabinet were there just in name. When his Attorney General once tried to put him right on an issue of law, he clearly told him 'you may be the Attorney but don't forget I am the General' (Achebe 1987: 22). The hands of his ministers were tied with the chains of dictatorship such that they were only 
pupates denied of using their initiatives. The popular disposition of the cabinet members is presented in this way:

Days are good or bad for us now according to how His Excellency gets out of bed in the morning. On a bad day, such as this one had suddenly become after many propitious auguries, there is nothing for it but to lie close to your hole, ready to scramble in and particularly to keep your mouth shut, for nothing is safe, not even the flattery we have become such experts in disguising as debates (Achebe 1987: 2).

Freedom of speech was totally subdued, and people were killed arbitrarily at the discretion of His Excellency, outside the provision of the law. The common man and poor people's plight was horrifying. Killings by firing squads were taking place here and there without recourse to fair hearing, and the end to such anomalies seemed not in view. The narrative gave the common man's remark as follows:

How does the poor man retain his calm in the face of such provocation? From what bottomless wells of patience does he draw? ... The very words the white master had said in his time about the black race as a whole. Now we say them about the poor (Achebe 1987: 40).

When Ikem, the National Gazette Editor, dared His Excellency and published true reports that favoured the plight of the poor, he was brutally tortured and killed by the government, and another editor was put in place that began to publish lies as the government desired. Of course, Ikem's death was falsely painted to be as a result of struggle with armed men over arrest that occasioned accidental discharge of the gun that got him fatally wounded. Chris was not happy with the development and tried to say the truth and his own hunt began, so he took to hiding and the waterloo continued to the end of the narrative.

\section{NIGERIAN SETTING OF THE NARRATIVE}

The military interregnum that informed Achebe's narrative came up with a coup d'état on $31^{\text {st }}$ December 1983 which ousted the democratic government of the Federation. This military regime under the leadership of General Muhammadu Buhari and subsequent ones after him were extremely hostile to constitutionality and the rule of law. At this regime the freedom of the press was absolutely severed and the courts accordingly could not show any form of activism even when there were obvious reasons to so do. The Public Officers (Protection against 
False Accusation) Decree No. 4 of 1984 shut up the voice of the press, while the Federal Military Government (Supremacy and Enforcement of Powers) Decree No. 13 of 1984 subdued the constitutional human rights and subsumed them to the whims and caprices of the military decrees and dictatorship.

With these the courts were completely out of steam and were cowed into simply upholding the shadows of law fashioned by the military government. This came up vividly in the case of Guardian Newspaper v. A.G. of the Federation where a publication of what is true was acknowledged by the court as such but judged an offence consequent upon the military decree in place. Adofarasin (1984: Suit No. M/139/84), Chief Judge of Lagos High Court (at that time) has this to say:

By the foregoing provision it is unlawful for a person to publish a report or statement which brings or is calculated to bring the Federal Military Government or a State Government or a public officer to ridicule or disrepute even when the publication is true... I would say that section 1 (1) of the Public Officers (Protection against False Accusation) Decree 1984 makes it unlawful for the plaintiffs to publish any report or statement which is true but which brings or is calculated to bring the Federal Military Government or a Public Officer to ridicule or disrepute. The provision may seem harsh but it is nonetheless the law of the land and none can question it.

In this way the judiciary under the military regime was mainly passive. Perhaps what summarizes the human rights status in Nigeria under the military regime of General Muhammadu Buhari is one of the questions Christiane Amanpour at CNN asked the same Muhammadu Buhari in 2015 as he was campaigning to be Nigeria's president in the civilian dispensation. Part of the questions and answers which Ademuwagun (2015: Online 18/3/17) reproduced went thus:

Amanpour: Can I now ask you about yourself because headlines around the world are portraying this election as a choice between a failed president and a former dictator and you're the former dictator according to these headlines. You know, people say - and they remember - that you expelled 70,000 migrants years ago thinking that would create jobs, that you've banned political meetings and free speech, that you've detained thousands of people, secret tribunals, 
executing people for crimes that were not capital offences. Have you changed or is this what the Nigerian people have to look forward to?

Buhari: Well, all those things you mentioned, with a degree of accuracy of actually what happened, was then under a military administration, and when that military administration came under my leadership, we - the military suspended the part of the constitution that we felt would be difficult for us to operate under those circumstances. So I think I'm being judged harshly as an individual that what happened during the military administration can be extended under a multiparty democracy system.

It was still within the time earlier to the publication of Anthills of the Savannah, precisely on October 19, 1986, under the military regime headed by Ibrahim Babangida, that a great Nigerian journalist, Dele Giwa was murdered through a letter bomb sent to him to silence him over his insistence in publishing articles that showed the atrocities committed by the government. As the $30^{\text {th }}$ anniversary of his death was marked in 2016, Premium Times of Monday, 28 March, 2016 carried a headline story titled 'Dele Giwa's Murder: Soyinka replies ex-police DIG, Omeben'. There, Kayode Soyinka who was at breakfast with Dele Giwa on the same table when the incident took place decried the human rights abuses in the military and police force of Nigeria, and pointed out how the police are just errand boys of the military dictatorship in perpetrating dehumanizing crimes against innocent Nigerians. The military would commit the crime and in alliance with the police, investigation would consciously be shifted towards the wrong direction to cover the culprits (Kayode-Adedeji 2015).

Today, in Nigeria, Muhammadu Buhari is the civilian president, and the expected freedom is still elusive. Still the things for which Christiane Amanpour of CNN asked him 'have you changed' are still experienced in Nigeria. The economy is collapsing with a free fall of the naira currency. The president made himself the petroleum minister and petroleum crisis is biting hard in the country even as the country is the sixth largest producers of crude oil in the world. Power supply is drastically dwindling. On Tuesday 29, March 2016 the federal minister for information Lai Mohammed, came on air in Nigeria Television Authority (NTA) in a live programme 'Good Morning Nigeria' to address the petroleum scarcity in the country and the unbearable economic hardship people are passing through since the government came to power. 
He apologized for the hard times being experienced and said that things would soon be better. However, he stated that petroleum products had been supplied by the federal government to five big cities in the country, and named them as Abuja, Lagos, Kano, Kaduna and Port Harcourt. Consequently, almost all southeastern states that harbor about a quarter of the total 180 million of the Nigerian population, which is the hometown of the native Igbo, the former Republic of Biafra, was entirely neglected in the rescue mission of the federal government, and that is part of the complaint of discrimination that led to the move for self-determination in secession, and consequent civil war, and since then worse things are still perpetrated against this region of Nigeria by the federal government without an end in view.

It would be recalled that shortly after the Buhari administration came to power in 2015 , the president visited the USA, and there a female journalist asked him a question as to how he intends to carry the different regions of the country along without discrimination so as to mellow down the age long injustice being perpetrated against some regions. There he gave an answer that shocked the whole world when he publicly declared that he would not treat Nigerians equally but based on the way they voted for him (Onyejiuwa 2015: Online 19/3/17). In his words:

(Going by election results) constituencies that gave me $97 \%$ cannot in all honesty be treated on some issues, with constituencies that gave me $5 \%$, I think these are political realities. While, certainly there will be justice for everybody but the people who voted, and made their votes count, they must feel the government has appreciated the effort they put in putting the government in place. I think this is really fair...

If that is fairness for him for universal consumption it is easier to understand the meaning of fairness and social justice among some government officials in Nigeria. Justice or fairness seems therefore to be the selfish interest of the person in power over the use of tax payers' money. One could then imagine how people from those regions classed as 5 per cent voters would be happily paying tax that would be used to congratulate the 97 per cent voters at the expense of the former? This explains why the blowing up of petroleum pipelines conveying the crude oil from the oil rich south ( 5 per cent area) to the non-oil north ( 97 per cent area) has resumed once again after being placated with the amnesty programme of the past administration. 
The Niger Delta region resorted once again to violence in protest against unfair treatment by the federal government. The people's cry for self-determination became high once again. The Nigerian National Petroleum Corporation (NNPC) in charge of the petroleum production and distribution gave a report showing that petroleum pipeline destruction by vandals had cost Nigeria the loss of 174.57 Billion in product and repair in recent years (NNPC 2015: Online 19/3/17).

People from the southeastern region that fought the civil war as the Republic of Biafra had since the end of the war in 1970, been crying over the worse condition the federal government has kept it. Now they have come up again in agitation for the resurrection of the Biafran state under the campaign of the Indigenous People of Biafra (IPOB) as they believe that they cannot be safe and happy in Nigeria. For the non-violent campaign launched by the leader of this group, Nnamdi Kanu, in Radio Biafra which operates from London, untold atrocities against them for their human rights struggle are everywhere in the news.

The federal government of Nigeria arrested Nnamdi Kanu when he visited the country shortly after Buhari came into power in 2015, and accused him of treasonable acts for the speeches made from the Radio Biafra, and held him in detention ever since, in defiance of the court order that granted him unconditional bail for having held him for more than two months in custody without trial, which is against the law of the land. Faloyin (2015) reported:

Nigeria's President Muhammadu Buhari speaks during the opening ceremony for the summit of Heads of State and Governments of the Lake Chad Basin Commission (LCBC) Nigeria June 11. On Wednesday, Buhari condemned the acts of Pro-Biafra campaigner Nnamdi Kanu - making them treasonable. Nigerian President Muhammadu Buhari says the government has no immediate plans to release Nnamdi Kanu from detention, despite a court granting the pro-Biafran campaigner unconditional bail in December. Kanu is the director of Radio Biafra and leader of the Indigenous People of Biafra (IPOB), a movement that seeks independence from Nigeria in order to form the Republic of Biafra in the South Eastern region of the country.

Since the arrest and detention of Kanu, the unarmed members of the Pro-Biafra agitation have been massacred here and there in their thousands. News of how 22 unarmed members of the IPOB were 
killed by security agents of the Nigerian government at the city of Aba while they were praying raged in Nigeria; the same is the case when they were picked from some Churches at Onitsha and killed as they slept there on the eve of the Biafra remembrance day scheduled to climax at the city. Reports have it that more than 1000 unarmed members of the IPOB had been killed since their leader Nnamdi Kanu was arrested in 2015 (Okoli, Nwaiwu, and Ugbor 2016). The hard-tocomprehend human rights abuses in Nigeria could go on endlessly. Section 14(3) of the Constitution of the Federal Republic of Nigeria 1999 provides as follows:

The composition of the Government of the Federation or any of its agencies and the conduct of its affairs shall be carried out in such a manner as to reflect the federal character of Nigeria and the need to promote national unity, and also to command national loyalty, thereby ensuring that there shall be no predominance of persons from a few states or from a few ethnic or other sectional groups in that Government or in any of its agencies.

This provision on federal character, though it has its own criticisms of being a tool in the hands of bad governments to stifle meritocracy and enthrone mediocrity, may actually have been inserted in the constitution to mellow down the ethnic hatred of some diehard dictators as already experienced in Nigerian leadership. People to be appointed in different positions in each government are expected to be spread across the different ethnic groups in the country since ethnic suspicion and hatred is very pronounced in the country. When Buhari entered into power as a civilian on 29 May 2015, the Nigerians were eagerly waiting for his appointments. The ethnic groups in Nigeria had been spread into six geopolitical zones of Northeast (NE), Northwest (NW, Buhari's zone), North-Central (NC), Southeast (SE, former Republic of Biafra), Southwest (SW), and South-south (SS, the Niger Delta).

As he kept on releasing the lists of appointees to take charge of key offices in the government of the federation within some months into his government, out of the first 27 key appointees the geopolitical spread is as follows: $\mathrm{NE}=6 ; \mathrm{NW}=11 ; \mathrm{NC}=3 ; \mathrm{SE}==0 ; \mathrm{SW}=3$; and $\mathrm{SS}=4$. As expected news carried it everywhere in the country and beyond (360NEWS 2015) that the civil war purported to have ended in 1970 is still very fresh almost half a century later, such that the youth that struggle for the revival of the State of Biafra are mainly 
those that virtually had no conscious experience of what happened during the war, but who live in a country where the situation is still as it was in those old years. Hence Achebe's narrative in the Anthills of the Savannah is still abreast with time in Nigeria.

\section{RECOMMENDATIONS}

Human rights are not hidden or require much education to be learnt so as to respect them, instead the dullest person in the society ordinarily knows of them naturally. That is why those who infringe on them may not claim any ignorance. As for the people whose rights are trampled upon it is necessary to speak out. Without speaking out in certain cases of infringement on human rights there is no way such infringements may be known to the world. Those who prefer to die in silence for the shame or fear of the negative consequences of self-expression in the face of tyranny should know that he/she who fights and runs away would live to keep fighting. But the one who persists in fighting to the end will only face it once. The courts are not Father Christmas as to grant justice to somebody who did not pray or ask for any redress. Yet, the problem is if justice is available in courts cowed by dictatorship of the executive.

The price of liberty is eternal vigilance. Nigerians should be able to keep struggling to free themselves from tyrannical rule. Part of the problem with leadership in Nigeria is that the constitution professed to give Nigeria a federation (in the likeness of the United States of America) but in practice it is a unitary system that is in place in view of the paradoxical give-and-take-backs in the constitutional provisions as handed down by the military government, and those who benefit from the discriminatory dictates of the constitution insist on not changing it for an egalitarian one. If power belongs to the people of Nigeria and not to the few people in political office nothing prevents Nigerians from making their intentions for redress known not only in speech (as is mainly the case) but also in peaceful demonstrations, organized mass protests, civil disobedience, industrial actions or even lawful revolutions to defend their rights. The much they had tried to do these had always resulted in loss of life, property and job from the hands of government officials that molest citizens with impunity.

Non-governmental organizations and some in the political class that pose to speak on behalf of their people should reduce their greed for illicit money and selfish interests and concentrate more on organizing and mobilizing the masses to further the ends they profess to pursue. They should also remove their unholy romance with enemies of their 
people in government to be truly what they profess to be since he who pays the piper dictates the tone. People who however find themselves in government should try to be truly honorable as they pose to be. They should seek more the good of the people they serve than the good of their pockets. They should aspire for good names rather than for the fatness of their coffers.

History, human rights and citizenship education should be seriously and frankly taught in schools in Nigeria, starting from the primary school up to the university level so that from youthful ages people should have known what the country had passed through in the past, learn how to respect other people as fellow citizens, and know their rights in the society so as to be able to fight for them before they get to the ages when fear and obsequious caution reduce people's poise to engage in acts of exceptional courage that break the chains of dictatorship and tyranny. Nigerians have been so cowed with awful acts of humiliation and alienation with impunity that it is almost becoming part of their nature than exception. It has to be reversed.

Over and above the foregoing is the need that the world should revisit the case of Biafra and see if its recognition as a sovereign state could checkmate the excesses of Nigerian government. The United Nations Organization (UNO) was formed in 1945 to make it impossible for any dictator to rise up again and terrorize people in the name of leadership. There had been several places where such intervention of the UNO had taken place; it can still take place in Nigeria to truly help the giant of Africa. Hence the need for a referendum in the Biafran side of Nigeria is now urgently over necessary. Ethnicity bites hard in Nigeria and breeds untold corruption and injustice in the country.

If the creation of Biafra is not immediately within reach, at least Nigeria should either go back to the three regional political structures it had at independence, or even to the six geopolitical regions that are only in place by popular acceptance without any legal backing. That would settle the mutual suspicion of the different peoples and encourage a healthy competition. It will also make the people to stop eying the resources in other regions or geopolitical zones while neglecting to put to use the ones in their own region or zone. This would also kill the discriminating drive in those holding public offices in terms of tribe, ethnicity, religion and culture; such that obnoxious and vexatious laws would no more be found in the constitution, all in the bid to protect sectional interests of the dictatorial lawmaker or head of government, against the people he intends to subdue and punish for what- 
ever intention. With this, impunity would be shown the exit door, and flexibility will advance economic growth and happier social life.

There should be true federalism in Nigeria whereby the principles of federalism would be functional. As for now, Nigeria only practices a moribund and distasteful unitary system of government while answering a federal republic. True federalism entails perfect fiscal and administrative autonomy of the federating units that pay agreed tax to the centre, with common military, foreign policy, and other identifiers of nationality being the domain of the central government. Each federating unit would control its resources, take care of its laws, which would not conflict with the agreed federal constitution, and then freely send lawmakers to the national assembly without any influence from the central government.

In this way federal legislators would function as they should, and not fear the vindictiveness of the president or the federal government. This reduces the cost of governance and nips in the bud the bribery and corruption in the legislature, executive and the judiciary. Good laws would then be made and protected. The situation where the federal government gathers all the monies from all states and shares it arbitrarily on monthly basis to the federating units, even to the local governments (most of which may be unknown to him) is very unproductive and absurd, but that is what happens in Nigeria. That is why the people cry of lack of justice and claim for resource control and keep fighting to be free from such slavery and discrimination.

\section{CONCLUSION}

The Nigerian efforts at state survival, purported democracy and respect of human rights so far are worse than the wasted efforts of drunken paddlers who tied their canoe to a tree at the bank of the river before drinking excessively and forgot to untie it after getting intoxicated and resumed paddling. The leaders of the country actually know the structural and constitutional deformities that keep it at a standstill but may be, deceitfully decided to keep mute. The purported democracy is nowhere to be found in the country, and human rights and social justice are merely being made mockery of. Perhaps one of the first things to be done to show that Nigeria, and indeed all Africa, is ready for statehood and democracy is to highlight the right to selfdetermination through series of referendum to know if the boundaries given to them by colonialists are to their (African) advantage or to the maximization of colonial interests and the sustenance of neocolonization into endless years of freedom as independent African states. 
Thereafter, each African state should tell itself the truth and be courageous to ask ethnic nationalities among each state to come to a round table to discuss how they can stay together as a country to make progress, and where they fail to agree to stay together, they should have the courage to separate into units of agreement and form separate states that would enjoy common grounds of unity and peaceful coexistence. Based on the agreements a constitution can be made and members of each state should be custodians of their destiny. They could then happily, without any deceit or fear of being lynched, love their country and be ready to sacrifice for its peace and progress. It is only then that meaningful progress could be made, and African states would stop being a laughing stock in the comity of nations.

\section{REFERENCES}

Achebe, C. 1987. Anthills of the Savannah. London: Heinemann Educational.

Achebe, C. 2012. There Was a Country (A Personal History of Biafra). London: Penguin Books.

Ademuwagun, A. 2015. Full Transcript of what Buhari said During Interview with Amanpour on CNN. NAIJ.com. URL: https://www.naija.ng/383841full-transcript-of-what-buhari-said-during-interview-with-amanpour-oncnn.html\#383841. Accessed March 18, 2017.

Aguda, T. A. 1983. The Judiciary in the Government of Nigeria. Ibadan: New Horn Press.

Akpabio, G. 2016. The Nigerian Question: Ethics in an Age of Uncertainty. In Kabiru, I. (ed.), Senator Akpabio - Why there is bloodshed in Nigeria today. Shakara Square. URL: https://shakarasquare.com/senator-akpabiowhy-there-is-bloodshed-in-nigeria-today. Accessed April 16, 2018.

Berger, K. 1989. Justice - Scripture. In Rahner, K. (ed.), Sacramentum Mundi. Vol. 3 (pp. 231-232). Bangalore: Theological Publications in India.

Crowder, M. 1966. The Story of Nigeria. London: Faber and Faber.

Ezejiofor, G. 1999. The Development of the Concept of Human Rights: Definition and Philosophical Foundations. In Obilade, A. O. (ed.), Text for Human Rights Teaching in Schools (p. 1). Lagos: Constitutional Rights Project.

Faloyin, D. 2015. President Buhari Calls Pro - Biafra Nnamdi Kanu's Acts 'Treasonable'. Newsweek, December 31. URL: http://europe.newsweek. com/president-buhari-angered-biafra-leader-nnamdi-kanu-treasonableacts-410454?rm. Accessed March 19, 2017.

Kayode-Adedeji, D. 2015. Dele Giwa's Murder: Soyinks Replies Ex - Police DIG, Omeben. Premium Times, October 29. URL: https://www. premiumtimesng.com/news/headlines/192320-dele-giwas-murder-soyinkareplies-ex-police-dig-omeben.html. Accessed March 18, 2017. 
NNPC 2015. How Pipeline Vandals Cripple Fuel Supply. URL: http://www. nnpcgroup.com/PublicRelations/NNPCinthenews/tabid/92/ArticleType. Accessed March 19, 2017.

Obegolu, C. E. N. 1999. Free and Fair Elections in Nigeria: Hindrances and Remedies. Enugu: Jimken.

Okoli, A., Nwaiwu, C., and Ugbor, E. 2016.Biafra: Over 1000 of our Members Killed since Kanu's Arrest, Detention - IPOB. Vanguard, February 11. URL: https://www.vanguardngr.com/2016/02/biafra-over-1000-ofour-members-killed-since-kanus-arrest-detention-ipob/. Accessed March $19,2017$.

Onyejiuwa, C. 2015. Muhammadu Buhari Says He Will Treat Nigerians Who Did Not Vote For Him Unequally. URL: https://www.youtube.com/ watch?v=ZYUBTU2ZgFY. Accessed March 19, 2017.

Oputa, C. 1998. The Independence of the Judiciary: Myth or Reality. In Amucheazi, E., and Olatawura, O. (eds.), The Judiciary and Democracy in Nigeria (p. 173). National Orientation Agency.

Permanent Observer Mission to the United Nations in New York 2011. Organization of Islamic Cooperation: Member States. URL: www.oicun.org/ 3/28. Accessed March 18, 2017.

Uwalaka, J. 2003. Igbos to Be or Not To Be? Enugu: SNAAP Press.

Vonnegut, K. 1974. Biafra: A People Betrayed. In Vonnegut, K. Wampeters, Foma and Granfalloons. Delacorte Press. URL: http://journeytofore ver.org/rrlib/biafra.html.

360NEWS 2015. Full List of Buhari's Appointments since Becoming President of Nigeria. URL: http://www.360nobs.com/2015/08/full-list-of-bu haris-appointments-since-becoming-president. Accessed March 19, 2017. 